and to address other needs as well, such as the public's thirst for discussion of functional anatomy, ecology, behaviour, and so on ${ }^{13}$, is also evident.

Malcolm C. McKenna

Department of Vertebrate Palaeontology, American Museum of Natural History, New York, USA

1. Halstead, L.B. Nature 275, 683 (1978)

2. Halstead, L.B. Nature 276, $759-760$ (1978).

3. Halstead, L.B., White, E.I. \& Macintyre, G.T. Nature 277 176 (1979)

4. Halstead, L.B. New Scientist 17 July 1980, 215-217 (1980).

5. Halstead, L.B. Nature 288, 208 (1980)

6. Halstead, L.B. Nature 289, 106-107 (1981).

7. Patterson, C., Forey, P.L., Greenwood, P.H., Miles, R.S. \& Jefferies, R.P.S. Nature 277, 175.176 (1979).

8. Fink, W.L. \& Wiley, E.O. Nature 280, 542 (1979).

8. Fink, W.L. \& Wiley, E.O. Nature 280,
9. Patterson, C. Nature 288, 430 (1980).

10. Popper, K. Unended Quest (Open Court Publishing, La Salle, Illinois, 1976)

11. Patterson, C. Evolution (Cornell University Press, 1978)

12. Donovan, D.T. Nature 289, 105-106 (1981).

13. Benton, M.J. Nature 289, 106 (1981).

SIR - I have read with diligence the continuing controversy sparked by Halstead.

Thus far I have had difficulty achieving a precise understanding of it. Now, however, certain matters are clear (Nature 1/8 January, p.106.) To sum up: Halstead dislikes the new exhibits at the British Museum (Natural History), and he would convince other persons that they, too, should dislike the exhibits. The argument he gives, as far as my evaluation goes, passes not from the ridiculous to the sublime, but emanates entirely from the low end of that spectrum. Knowing Halstead to be usually of good cheer and judgement, I am led to suspect that not all is as it might seem that the root of his dislike is not to be found brewing in a pot pourri of punctuated equilibria, Marxism, scholastic death, etc. Rather, his dislike may stem, as seems to me, from a sense of loss of "the fossil record" the ultimate source of the truth of evolution as rendered by a professional class of fellowspecialists. To the dismay, sometimes acute, of the more clerically minded members of this profession, cladistics treats fossils in a secular fashion - not as revelation but as some among many other biological specimens subject to interpretation that is apt, indeed expected, to be diverse, especially with respect to details (for example, the true nature of the "Petralona skull"). As reasonable as this treatment might seem to the outsider, the emotional effect within such a palaeontologist involuntarily confronted with cladistics (as I have witnessed on more occasions than I care to remember) is not unlike that apt to be experienced by a fundamentalist minister who has forced upon him uninvited the notion that the Bible is just one book among many.

Suffice it to say that more than one kind of church has been built upon rock.

So what now? Here in the States creationists dislike the museums' secular exhibits on evolution and the schools' secular treatment of that subject. In Britain a palaeontologist dislikes secular exhibits on the "fossil record". The forms are similar, but the substances at first glance seem utterly different.

Palaeontology, after all, is nominally a science, and a rational mind can easily defend it as such. The problem I have with Halstead's defence, if I may term it that, is reconciling it with a standard of rationality.

Gareth Nelson

Department of Ichthyology,

American Museum of Natural History,

New York, USA

\section{Genes and racism}

SIR - Steven Rose notes in his recent letter (Nature 22 January, p.335) that a National Front journal New Nation has claimed to find support for racism in my writings on sociobiology, as well as in those of Dawkins and Maynard Smith. Rose calls on the latter two authors to dissociate themselves from such misuse, although curiously he does not extend the same invitation to me. To keep the record straight, I am happy to point out that no justification for racism is to be found in the truly scientific study of the biological basis of social behaviour. As I stated in On Human Nature, "I will go further and suggest that hope and pride and not despair are the ultimate legacy of genetic diversity, because we are a single species, not two or more, one great breeding system through which genes flow and mix in each generation. Because of that flux, mankind viewed over many generations shares a single human nature within which relatively minor hereditary influences recycle through ever changing patterns, between the sexes and across families and entire populations".

If there is a possible hereditary tendency to acquire xenophobia and nationalist feelings, it is a non sequitur to interpret such a hypothesis as an argument in favour of racist ideology. It is more reasonable to assume that a knowledge of such a hereditary basis can lead to the circumvention of destructive behaviour such as racism, just as a knowledge of the hereditary basis of haemoglobin chemistry and insulin production can lead to the amelioration of their pathological variants.

I now call on Professor Rose to consider these and similar arguments raised in my writings. It is my hope that he will not confine himself, as he has in the past, to arguments that link sociobiology to racism and thus to continue to abet the very misuse which he piously claims to deplore.

EDWARD O. WILSON

Harvard University, Cambridge,

Massachusetts, USA

\section{Origin of cancer}

SIR - John Cairns' article on "The origin of human cancer"' (Nature, 29 January 1981, pages 353-357) dismisses the importance of chemical mutagens in human cancer aetiology on, we believe, very tenuous grounds. $\mathrm{He}$ argues that there must be a single underlying mechanism for tumour production and that this is not through point mutation. As your leading article (Nature, 5 February 1981) quite rightly points out, why should there be a single mechanism for cancer development? Indeed, can one say that cancer is even a single disease? Cairns' article appears to us to be a simplistic approach to a complex problem. We all would like to have the answer to how a cancer cell develops, but can one say that Cairns' article will lead us any nearer to the truth? Why should workers in the field of chemical carcinogenesis abandon a large body of work which may be getting somewhere near to establishing why populations differ in cancer incidence, and substitute a hypothesis of genetic transposition bearing in mind that, as Cairns writes, it is not yet clear whether transposition is important in vertebrate development. Should we abandon the somatic mutation theory of cancer for a hypothesis with no experimental evidence? Furthermore, why should mutagens/carcinogens only act through point mutations? It is well recognized, as Cairns states, that agents reacting with mammalian cell DNA can cause gross effects such as chromosome aberrations, sister chromatid exchanges, deletions, and so on. Just because one measures DNA reaction in bacteria with a point mutation system does not mean a priori that this is the mechanism of action of these chemicals in mammalian cells. After all, bacteria don't even get cancer. Bacteria are merely used for carcinogen screening because they are cheap and mutations are easy to score.

Where Cairns' article is mischievous is in suggesting that people are wasting their time looking for carcinogens in the environment and then, having identified them, seeking to reduce exposure. The fact is that if people would stop exposing themselves and their immediate families to mutagens/carcinogens in the form of cigarette smoke, a large proportion of cancers would be prevented (besides a large proportion of coronary heart disease, lung disorders, etc.). If Cairns accepts that smoking is bad for one, why should he not accept that other environmental insults might also be carcinogenic? To say that animal carcinogens induce mainly liver cancer, that humans don't normally get cancer of this organ, and therefore animal liver carcinogens have nothing to do with human cancer shows a complete unawareness of chemical carcinogenesis. Most chemicals which have been identified as human carcinogens do not give the same spectrum of tumours in animals as in humans, for example benzidine causes bladder cancer in man but liver cancer in animals.

Cairns' main argument for DNA reaction being unimportant in carcinogenesis is the finding that in xeroderma pigmentosum patients, few if any internal cancers have been seen. Why should one expect an increased incidence of lung cancer, for example, in these patients? Is the skin the same as the lung in its function, biochemistry, enzyme profile, etc.? Why should we expect the mechanism of skin cancer to be the same as for internal organs? Do xeroderma pigmentosum patients live in the same environment as the normal population? I don't think one has to indulge in "special pleading" to support the case of somatic mutation as being important in cancer production. The majority of facts available tend to support the somatic mutation hypothesis. When there are sufficient data available to overthrow this hypothesis, then is the time for it to be abandoned. In the meantime, those of us working in chemical carcinogenesis will carry on identifying carcinogens in the environment and recommending that exposure be reduced. Whether society (or Cairns) listens to us is entirely up to them.

Cancer Research Unit,

University of York, York, UK 